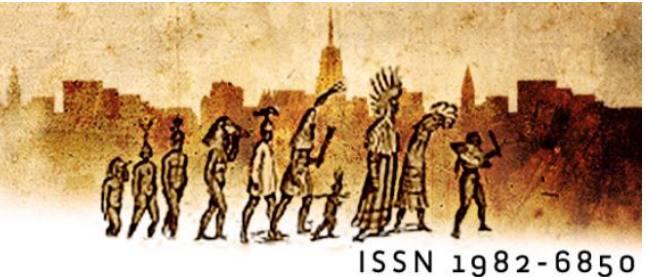

\title{
O irreversivel que infinitamente se reescreve: a força do documento-suplemento na filosofia de Jacques Derrida
}

Aline Magalhães Pintoi

\begin{abstract}
Se nada precedeu a repetição, se nenhum presente vigiou o traço, se, de certo modo, é o vazio que de novo se escava e se marca de impressões digitais, então o tempo da escrita não segue mais a linha dos presentes modificados. O futuro não é um presente futuro, ontem não é um presente passado. O além do fechamento do livro não deve ser esperado nem encontrado. Está lá mas além, na repetição mas evitando-a. Está lá como a sombra do livro, o terceiro no agora da escrita, a distância entre o livro e o livro, essa outra mão... Jacques Derrida.
\end{abstract}

\section{O texto, a escrita, o pensamento derridiano}

Remeter à escrita e, em consequência, ao texto não significa abstrair-se numa "realidade" que só existe cerrada num "livro". Na escrita derridiana, texto não se limita ao livro, ao discurso. Não se restringe à esfera semântica, representativa, simbólica, ideal ou ideológica. A textualidade implica todas as estruturas ditas "reais", "econômicas", "históricas", "sócio-institucionais", em suma, todos os referenciais possíveis. Não há um fora do texto, o que não quer dizer que todos os referenciais estão suspensos ou negados. Ou ainda que todos estejam legitimados numa espécie de "vale-tudo". Quer dizer tão somente que todo referencial, todas as realidades, têm a estrutura de um traço diferencial, são textuais, e só nos podemos reportar a esse real numa experiência interpretativa que se dá, ou só assume sentido, num movimento diferencial. O texto é esse lugar que viaja entre as diferentes dimensões do vivido (DERRIDA, 2004, p. 79-80). 
A escrita derridiana é contemporânea do que se convencionou chamar de "reviravolta linguística" e que caracteriza boa parte do pensamento filosófico no século XX. Interessa-se pelo funcionamento da linguagem, suas relações com a cultura, saberes e práticas, pelas possibilidades da problemática do signo. O foco de sua investigação parte da constatação de que tudo que se subtrai ao jogo da linguagem só pode ser retomado na linguagem (idem, p.7).

Neste contexto, a linguagem aparece sem limites. O significado infinito, que parecia excedê-la, deixa de cercá-la e contê-la. Mas a essa valorização segue-se um processo de inflação que culmina na banalização do signo linguagem. Este é um dos indícios que permite a Derrida entrever um deslocamento da linguagem para a escrita (ibidem, p.73-76).

Se, por lidar com o significante do significante e ser considerada uma reduplicação, uma cópia da fala, a escrita ocupava um papel secundário como forma auxiliar da linguagem entendida como comunicação, expressão e significação, agora, como "significante do significante", a escrita descreve o próprio movimento da linguagem. A linguagem é entendida como um conjunto de unidades cujo sentido é dado por seu caráter diferencial com relação aos demais signos, ou seja, uma escrita. A linguagem produz mais iteração que comunicação. Ela é um momento, um fenômeno, um aspecto, uma espécie da escrita. Não há sentido em si, apenas ao diferenciar-se o sentido se efetiva (ibidem, p.8 et seq.).

Este ultrapassar da escrita sobre a linguagem se esboça como abertura ao jogo, onde o sentido arrebata-se e apaga-se em sua própria produção. O cunho cindido entre leitura e escrita abre a possibilidade de acesso ao texto como repetição noutro lugar. Lugar no qual o "leitor"1 é destronado da posição meramente especulativa imposta por uma receptividade ansiosa por expansão, progresso, evolução, futuro, autenticidade, coerência, verdade. ${ }^{2}$

\footnotetext{
${ }^{1}$ As aspas entre as quais se situa o leitor não indicam uma morte, senão um deslocamento: "Há um leitormodelo não só para Finnegans Wake, como ainda para os horários de trem, e de cada um deles o texto espera um tipo diferente de cooperação". Um "leitor" derridiano, se existe, está mais para "um leitor ideal acometido de uma insônia ideal', instruído a desbravar os bosques perdidos num texto, mais do que para aquele que, na estação, observa o trem da história seguir. Cf. Calvino, Italo. Seis passeios pelos bosques da ficção. São Paulo: Companhia das Letras, 1994. p.7.

${ }^{2}$ A forma de recepção da qual se desvia é aquela intimamente relacionada ao predomínio de um sentido histórico positivo e inexorável, dentro do qual a estrutura e o tempo de um texto são considerados de tal
} 
As primeiras publicações de Derrida datam da década de 6o, num momento em que a fenomenologia, estabelecida com autores como Sartre e Merleau-Ponty como tradição no pensamento filosófico francês, está sendo contestada pelo estruturalismo. Com seus estudos sobre Husserl, a introdução de $A$ origem da geometria e $A$ voz e o fenômeno, Derrida parecia correr a favor da tradição. ${ }^{3}$ Entretanto, nas obras seguintes propõe uma radicalização da fenomenologia, de maneira a transpor a objeção estruturalista e encontrar-se além dela. Suas desconstruções passam então a mover uma guerra contra o estruturalismo, conduzida dentro deste contexto, pela necessidade, sentida na segunda metade da década de 6o, de dinamizar a ordem das estruturas, de as historicizar. ${ }^{4}$ Paradoxalmente, ao promover um questionamento radical a respeito de toda substantivação, de toda essência fundadora, pode ser considerado aquele que levou ao extremo a lógica estruturalista (ibidem, p.39 et seq.)

Imerso num cenário intelectual em que se debatem, com fervor e polêmica, estruturalismo e história, Derrida convoca ambos em suas primeiras desconstruções, notadamente nos ensaios de $A$ escritura e a diferença. A escrita derridiana recorre à história quando confrontada com teorias essencialistas ou argumentos a-históricos. Ao mesmo tempo a denuncia como cúmplice da metafísica ocidental: a história tem sido uma história do sentido, do telos, ou do fim da humanidade realizando-se; tem sido a história do presente, da presença consciente a si (CULLER, 1997, p. 146-150).

O procedimento desconstrutor vem, desta maneira, solicitar a noção de história. Recuperando as tensões despertadas pela obra de Lévi-Strauss, Derrida indica a cena dessa solicitação:

\footnotetext{
maneira compactos a não oferecerem ao "leitor" senão sua "verdade". Cf. Hutcheon, Linda. Poética do pósmodernismo: História, teoria e ficção. Rio de Janeiro: Imago, 1991. p.11-25.

3 Sobre as vias pelas quais a fenomenologia francesa de meados do século XX pode ter preparado o terreno para que filósofos como Derrida ou Deleuze prolongassem, ampliassem e deslocassem a reflexão a respeito do sentido do corpo e dos fenômenos ontológico-estéticos que conduziu à delineação de uma metaestética do sentido, cf. Huchet, Stéphane. Meta-estética e ética francesa do sentido (Derrida, Deleuze, Serres, Nancy). Kriterion, Belo Horizonte, v.45, n.110, july./dec.2004.

${ }^{4}$ Esta necessidade permitirá aos historiadores dos Annales, depois de 1968, colher os frutos da implosão do paradigma estrutural, dando uma continuidade transformadora à aventura estruturalista, no que se chamou "Nova História". Destacam-se os autores Pierre Nora, Le Goff, Le Roy Ladurie, Marc Ferro, André Burguière e Jacques Revel, que desenvolvem suas obras a partir da conexão fundamental aberta por Foucault. (DOSSE, François. A idade de ouro da nova história. In: História do estruturalismo. São Paulo: Ensaio; Campinas, SP:

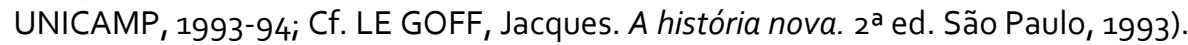


(...) ao reduzir a história, Lévi-Strauss tratou como merece um conceito que sempre foi cúmplice de uma metafísica teológica e escatológica, isto é, paradoxalmente essa filosofia da presença à qual se julgou poder opor a história. A temática da historicidade, embora pareça introduzir-se bem mais tarde na filosofia, sempre foi nela requerida pela determinação do ser como presença. Com ou sem etimologia, e apesar do antagonismo clássico que opõe estas significações em todo pensamento clássico, poderíamos mostrar que o conceito de episteme sempre chamou o de istoria, se a história é sempre a unidade de um devir, como tradição de verdade ou desenvolvimento da ciência orientado para a apropriação da verdade na presença e a presença a si, para o saber na consciência de si. A história sempre foi pensada como movimento de reassunção da história, derivação entre duas presenças. Mas, se é legítimo pôr em dúvida este conceito de história, corremos o risco, ao reduzi-lo (...) de cair novamente num anistoricismo de forma clássica, isto é, num momento determinado da história da metafísica. (DERRIDA, 1995, p. 246-247, grifo meu)

Para Derrida, a escrita da história aparece como o ângulo de dobra entre a afirmação e a suspeição da possibilidade de história. Esta escrita convoca um processoprocedimento no qual a consciência presente se torna uma função numa estrutura de reenvio generalizado. Já não cabe num livro, como ideia de uma totalidade natural, finita ou infinita. Os limites, as fronteiras, as distinções, terão sido sacudidas por um sismo e uma desfiguração.

a desfiguração te lembra que não habitas teu rosto porque tens bastantes lugares, tens lugar em mais lugares que o necessário, e a transgressão mesmo que viola sempre um lugar, uma linha intransponível, ela se capta, pune, paralisa instantaneamente, a topologia aqui sendo e não sendo mais uma figura, e se é uma desfiguração, eis o tropo que há pouco me foi enfiado goela abaixo por ter violado os lugares, todos, os lugares sagrados, os lugares de culto, os lugares dos mortos, os lugares da retórica, os lugares da habitação, tudo o que venero, não o imprevisível evento que eu teria escrito, eu, nomeadamente as frases próprias para fissurar o geologicial, não, isso se passou fora da escrita que vocês lêem, no meu corpo se preferem. (DERRIDA, 1994, p. 94)

Precisamente porque não há um reverso reservado, porque não se pode colaborar com o encadeamento do sentido, do tempo linear e do verdadeiro no discurso, é que já não se pode laborar seguramente. Instala-se a modalidade do talvez, ousadia de não poder senão afirmar a dúvida. Não há tranquilidade. Ofuscada a luz das certezas, cada gesto textual deverá agora ser explorado, historicamente, em sua própria ficção. Ao fazê- 
lo, evidencia que a escrita é sempre outra que um sujeito, que uma obra, um livro, que um lugar do mundo, em qualquer sentido que ela seja entendida.

(...) o escritor escreve em uma língua e em uma lógica cujo próprio sistema, leis e vida seu discurso, por definição, não pode dominar absolutamente. Ele apenas os usa, deixando-se, de certo modo e até certo ponto, ser governado pelo sistema. E a leitura deve sempre objetivar um certo relacionamento, despercebido pelo escritor, entre o que ele comanda e o que ele não comanda nos padrões de língua que usa. Esse relacionamento não é uma certa distribuição quantitativa de luz e escuridão, de fraqueza e força, mas uma estrutura significante, que a leitura deve produzir. O que quer aqui dizer produzir? (...) Uma tarefa de leitura. (DERRIDA, 2004, p. 193-194.)

Por desconstrução, a escrita disseminada busca ler no jogo das implicações estruturais a mobilidade e entroncamento dos estratos sedimentares, complexos e nãolineares, para que essa mesma configuração dê lugar a transformações surpreendentes, trocas, defasamentos, recuos, deslocamentos...(DERRIDA, 1996, p. 193-195).

Neste cenário, a produção é desde sempre uma contaminação. A escrita de história não é puramente atual, plena, presente e consciente; como não será uma pura dispersão, ininteligibilidade, morte. Não será mais "real" do que "ficcional", como também não contará mais "mentiras" que "verdades". 5 Nada está isento, casto, irrepreensível. Por onde o trabalho historiador passou, recolhendo, recortando, selecionando, confrontando, discutindo, reiterando, tudo se contaminou. A impossibilidade de higienização de um "realmente acontecido" como "fato" condena este trabalho a estar sempre nesse meio, nesse entre fronteiras (DERRIDA, 1996, p. 83).

Não que o trabalho do historiador tenha sido, ao longo de sua trajetória, de sua história, um suceder de "erros" e "mentiras" em série, nos quais acreditamos por muito tempo, e, agora, estamos prontos a abandonar. Confirmado o limite da historicidade da consciência presente, abre-se o des-limite de uma historicidade ausente (do inconsciente?), mas possível. Esta historicidade outra não elimina a anterior, lança-a para além de si própria e de sua lei fechada (DERRIDA, 1996, p.7-39).

\footnotetext{
${ }^{5} \mathrm{O}$ que não quer dizer que o trabalho historiador e o literário sejam iguais, como também não diferem por substância ou essência. Como lembra Costa Lima, história e literatura são distintos, "mas não porque um fale a verdade e outro seja fantasioso. Ambos são prejudicados pela carência [teórica] que, no Ocidente, acompanha suas práticas."O desafio que a escrita derridiana ajuda a dar corpo é a forma como esses saberes podem experimentar-se mutuamente e o que resulta disso". Cf. COSTA LIMA, Luís. História. Ficção. Literatura. São Paulo: Companhia das Letras, 2006, p.16-19.
} 
Instalada desde sempre no espaço cindido entre "real" e "ficcional", a escrita disseminada passa da possibilidade como eventualidade (contaminação como "evento" que só se apresentaria uma vez no mundo) à possibilidade como necessidade, uma contaminação irredutível entre territórios que toda uma tradição quis ver separados por uma fronteira intransponível, quais sejam arte e ciência, verdade e ficção, literatura e história (DERRIDA, 1996, p. 82 et seq.).

Numa fronteira, interdito e passagem se contaminam. Dobra de si pela qual se escreve, mas estraga-se na interrogação infinita sobre sua possibilidade. Nas faces contrapostas das páginas desta escrita porvir, desvia-se da busca por um passado com o qual controlar o futuro. ${ }^{6} \mathrm{O}$ lugar de onde ela parte não é um espaço fechado, localidade de exclusão, um gueto. Não é o Aqui empírico e nacional de um território. Escrever a partir de um lugar não é necessariamente tomá-lo como propriedade para encerrá-lo dentro de um discurso de representação a ser fixado e reificado. A escrita disseminada, itinerante, faz sulcos nos territórios por onde passa. Inventa um caminho inencontrável. Mas ao mesmo tempo em que desenha, ela reconhece os gestos que produz (DERRIDA, 1995 p. 58-60).

Como um registro nômade, a escrita derridiana trabalha a historicidade dos textos como uma prática de interpretação que não reconstrói um sistema ou uma totalidade, mas encena o deslizamento e traslado dos sentidos de um texto a outro, reinscrevendo estes traços e os relançando novamente à interpretação e a inquietude. Abandona-se a história para lhe dar passagem, multiplicar seus indícios, para que o registro histórico adentre suas fronteiras proibidas, forçando o deslocamento das demarcações que definem o que é e o que não é história (DERRIDA, 1972, p. 209 et seq.).

A suspeição do saber histórico como uma unicidade (unidade, entre grafia e sentido transcendente, que sempre se furtou) remete e instala o trabalho historiador no limite indecidivel entre os dois tipos de interpretação apresentados por Derrida em $A$ estrutura, o jogo e o signo no discurso das ciências humanas (DERRIDA, 1995, p. 249).

\footnotetext{
6 "A busca por um passado com o qual tentar controlar o futuro é inseparável da natureza humana: é o que significa quando dizemos aprender com a experiência." Aqui o historiador inglês John Lewis Gaddis enuncia claramente o que é tratado, em geral de maneira implícita pelos historiadores, tal seja: considerar uma espécie de atributo da essência humana a tendência a reconstruir passados com a perspectiva de conter a liberdade de outrem no futuro. Essa "natureza" humana é, sem dúvida, algo a se desconstruir. Cf. GADDIS, John Lewis. A perspectiva do historiador. In: Paisagens da história: como os historiadores mapeiam o passado. Rio de Janeiro: Campus, 2003. p.163.
} 
Na medida em que a cumplicidade metafísica não pode desaparecer, história(s) deve oscilar entre a afirmação da errância e a busca por verdades numa operação em que uma coisa está sempre por contaminar outra, pois é uma escrita que experimenta a impossibilidade de alguma vez ser no presente, de ser resumida com sentido unívoco em qualquer simultaneidade ou instantaneidade absolutas.

Nietzsche opõe, em Sobre a verdade e a mentira no sentido extra-moral, dois tipos humanos: o homem racional e o intuitivo. No que pode ser lido como uma paráfrase, Derrida diz sobre duas interpretações:

Uma procura decifrar, sonha decifrar uma verdade ou uma origem que escapam ao jogo e à ordem do signo, e sente como um exílio a necessidade de interpretação. A outra, que já não está mais voltada para a origem, afirma o jogo e procura superar o homem e o humanismo, sendo o nome do homem o desse ser que, através da história da Metafísica ou da onto-teologia, isto é, da totalidade da sua história, sonhou a presença plena, o fundamento tranqüilizador, a origem e o fim do jogo.(DERRIDA, 1995, 249)

A primeira posição, atitude do homem racional, se coloca frente à outra, postura do homem intuitivo. Mas, para Derrida, não se trata de opô-las numa luta pelo domínio da vida. Elas são inconciliáveis e conciliáveis numa economia obscura. Num dilema no qual não cabe uma escolha, o único imperativo é continuar a escrever, a interpretar (NORRIS, 1989, p.187-198)

Os acenos do pensamento desconstrutor no sentido de afiançar a indecidibilidade entre jogo e "verdade" foram vistos no coração do campo historiográfico tradicional como uma retórica e irônica fuga da "realidade". Diz Ginzburg a respeito do artigo supracitado de Derrida:

Entre duas faces contrapostas, Derrida declarava ironicamente não desejar escolher. Na realidade toda a intervenção, a começar pelo título, seguia na direção de Nietzsche e do ludo. A verdade era liquidada em favor da interpretação ativa, isto é, despojada de constrangimentos e limites; o Ocidente era incriminado por ser logocêntrico e contemporaneamente absolvido em nome da inocência do devir proclamada por Nietzsche. (GINZBURG, 2002, p.36.) 
A indecidibilidade do jogo desconstrutor é lida como "retórica de absolvição" e falta de compromisso com o que "realmente" existe, na medida em que reduz a verdade a um conjunto de "tropos". A espera de uma "desforra da realidade" que possa finalmente afastar de forma definitiva a perniciosa "maré pós-moderna", os discursos zelosos dos valores "morais" e "humanos" constituem o momento em que a metafísica da presença retoma o controle dos limites e o domínio da historicidade, fazendo valer a resistência ao jogo desconstrutor, demonstrando a "impertinência" da disseminação de sentidos como "defesa moral" do "patrimônio humano" (ibidem, p.35-38.)

Este é um momento ao qual sempre se retorna, por hierarquia e envolvimento, e do qual sempre se escapa por uma abertura que jamais se provará filosoficamente necessária, mas que insiste em tornar indomesticáveis as margens da necessidade (DERRIDA, 1991, p. 27-31).

\section{Realismo, realidade e sujeito}

Escapa às críticas mais ásperas feitas ao pensamento desconstrutor o fato de que o jogo de interpretações não se refere em absoluto a um conjunto de movimentos arbitrários de um sujeito que, "conscientemente" ou abandonado a surrealístico inconsciente criativo, concebe imagens de realidade (VATTIMO, 2001, p.18-21).

A defesa da "realidade" nestas críticas se faz à custa da condenação de tudo que parece aos olhos dos "realistas" pouco "real". 7

Essa noção de "realidade" se construiu por meio de uma historicidade encarnado num (improvável) sujeito universal, herói do conhecimento e da liberdade. É por romper com o universalismo do conceito de sujeito que a desconstrução é acusada não somente de "irreal", mas de irresponsável e antiética. A emancipação moderna tem seu núcleo normativo centrado no sujeito de uma história universal. A experiência desse tipo de sujeito é uma aposta na eternidade do presente, como medo de perder a identidade, e o desejo de que o outro se torne Eu. Desestabilizá-lo seria ameaçar seriamente as ideias de

\footnotetext{
7 "O real: palavra traiçoeira, armadilha metafísica. Pois quando se pergunta - o que é o real? a primeira tentação é responder negativamente: o que não é ideal; o que não é ilusão; o que não é fantasia. Como se a fantasia, a idéia e a ilusão fossem irreais, no sentido pleno do termo: não fossem de todo. Não não-ser: eis o real. O que é o mesmo que dizer: o real é o que é. Parece uma redundância vazia, e não é (...) Real é o outronome-de-mim.". (D'AMARAL, Márcio Tavares. O homem sem fundamentos: sobre linguagem, sujeito e tempo. Rio de Janeiro: Ed. UFRJ; Tempo Brasileiro, 1995).
} 
Homem, de humanidade, e os valores que as acompanham: liberdade, autonomia, igualdade... (DUQUE-ESTRADA, 2005, p.245-255).

É exatamente a noção de "sujeito moderno" - centrado, unificado, autônomo, autossuficiente, dotado das capacidades de razão, consciência e ação - que se desconstrói diante do traço. ${ }^{8}$

O tempo textualizado como economia de uma escrita que desponta a partir da disseminação do sentido em história está a ponto de deserdar o sujeito de seu espaço, porque lapida de espaçamentos o que outrora era tempo linear, lógico, da consciência, da representação verbal. Disso não resulta a "morte" do sujeito. O sujeito não é nem um indivíduo inserido numa série de outros, nem a soma particular de diferentes séries dele mesmo. 9

Mas, tão somente, "ele é" um sistema de relações entre as diferentes camadas textuais, psíquica, da sociedade, do mundo, e não a solidão soberana do escritor, leitor ou agente (DERRIDA, 1995, p.208/222).

Ao interpretar, escrever e ler, historiar: "ali eu estou, me encontro e me reencontro interessado, num texto que me transborda de todos os lados, mesmo onde não sei nada, onde não poderia reapropriar-me dele em consciência" (DERRIDA, 1996, p.4).

O sujeito "foi descansar" e em seu lugar há a máquina, aparelho que não funciona sozinho, mas em conjunto, em suplemento, suprindo sua finitude com o trabalho de se fazer e de se apagar (DERRIDA, 2001, p. 33-35).

Toda inquietação histórica deságua numa máquina de escrita, sistema de gestos, coordenação de iniciativas independentes, multiplicidade de origens que deveria desequilibrar o espaço do corpo próprio. Escrever é ausentar-se, estar num limiar, ser passante e, ao mesmo tempo, construtor e desconstrutor das vias que atravessa. Os traços produzem seu espaço de inscrição na duração de seu desaparecer.

\footnotetext{
${ }^{8}$ Esta concepção é claramente iluminista, e mesmo a versão mais sociológica construída em fins do XIX e no XX mantém o núcleo interior e racional dos indivíduos, ainda que admita que este núcleo se forme na interação com o meio social. Cf. HALL, S. Identidade cultural na pós-modernidade. Rio de Janeiro, DP\&A, 2003.

9 "Liquidação, eliminação ou dissolução do sujeito é uma falsa imputação. A desconstrução do sujeito - mas isso vale também, como Derrida faz questão de deixar claro com freqüência, para muitas outras formas de questionamento do sujeito que se desenvolveram notadamente na França por autores como Foucault, Deleuze, Lyotard e outros - significa antes um questionamento e um deslocamento de sua pretensa centralidade, de seu pretenso caráter originário ou fundamental. O sujeito passa a ser pensado a partir de múltiplas determinações, como ocupando um lugar numa certa economia, (...) numa rede mais ampla de conceitos." DUQUE-ESTRADA, Paulo César. Op.cit. In: NASCIMENTO, Evando. (org), 2005, p. 253.
} 
Seguindo o caminhar das metáforas do caminho, do traço, da exploração, da marcha, sulcando uma via aberta por efração através do neurônio, a luz ou a cera, a madeira ou a resina para se inscrever violentamente numa natureza, numa matéria, numa matriz, seguindo a referência infatigável a uma ponta seca e a uma escrita sem tinta; seguindo a inventividade incansável e a renovação onírica dos modelos mecânicos, essa metonímia trabalhando indefinidamente a mesma metáfora, substituindo obstinadamente os traços pelos traços e as máquinas pelas máquinas (DERRIDA,1995, p.225).

A cena da escrita desdobra-se, repete-se e denuncia a si mesma.

As fontes documentais são os limiares da fronteira entre história e ficção. $O$ trabalho historiador cambia junto com o status e a forma como se tratam estes textos. Certamente já não se pode mais afirmar a possibilidade de uma objetiva realidade histórica extraída dos "documentos" de uma forma totalizante. Mas ainda que o trato "positivista" a um "documento" isento, neutro, objetivo, científico, que comportava e comprovava toda a "realidade histórica" tenha sido praticamente abandonado, para o trabalho historiador a questão do documento e das fontes continua uma problemática. ${ }^{10}$

Uma das marcas mais relevantes do deslocamento ocorrido no interior do campo historiográfico com relação ao tratamento das fontes é o texto "Documentomonumento", de Le Goff (2003), no qual se anuncia não somente um conceito de documento, mas uma tarefa e função para a ciência histórica: ${ }^{11}$

O documento não é inócuo. É, antes de mais nada, o resultado de uma montagem, consciente ou inconsciente, da história, da época, da sociedade que o produziram, mas também das épocas sucessivas durante as quais continuou a viver, talvez esquecido, durante as quais continuou a ser manipulado, ainda que pelo silêncio. O documento é uma coisa que fica, que dura, e o testemunho, o ensinamento que ele traz devem ser em primeiro lugar analisados, desmistificando-lhe seu significado aparente. $\mathrm{O}$ documento é monumento. Resulta do esforço

\footnotetext{
${ }^{10}$ Há uma extensa bibliografia que aborda a relação do historiador e os documentos. De relance, citam-se: COLLINGWOOD, Robin George. The limits of the historical knowlodge. In: Essays in the philosophy of history. New York: McGraw-Hill, 1965. p.90-103; CARR, Edward Hallet. O historiador e seus fatos. In: Que é história? Rio de Janeiro: Paz e Terra, 1976. p.11-29; MARROU, Henri-Irenee. A história faz-se com documentos. In: Sobre o conhecimento histórico. Rio de Janeiro: Zahar, 1978, p.55-77.

${ }^{11} \mathrm{~A}$ abertura e ampliação do que era tido como documento e fonte, para além do que é "escrito", marcando a aceitação de outras linguagens como evidência e prova histórica, é também um acontecimento relevante. Depois dos trabalhos de Febvre, a noção de documento abrangerá cada vez mais "vestígios" de manifestações humanas a caminho de uma história total. Cf. FEBVRE, Lucien Paul Victor. Combates pela história. $3^{\mathrm{a}}$ ed. Lisboa: Presença, 1989.
} 
das sociedades históricas para impor ao futuro - voluntária ou involuntariamente - determinada imagem de si próprias. No limite, não existe um documento-verdade. Todo documento é mentira. (LE GOFF, 2003, p.538.)

Numa concepção apoiada nas reflexões foucaultianas a respeito das unidades e formações discursivas, ${ }^{12}$ a tarefa da história diante o documento passa a ser, sobretudo, tratar de pôr à luz as condições de sua produção e mostrar em que medida este documento é instrumento de um poder (LE GOFF, 2003, p.525).

Neste cenário, a pretensão de validade do trabalho historiador como ciência está assegurada na medida em que, por meio de "exame crítico" das fontes, o historiador consegue acionar formalizações científicas em seus objetos não científicos. O pesquisador não pode ser pueril e deve, portanto, extrair a "verdade" da mentira que o documento carrega. O exame crítico das fontes, isto é, situar os documentos no tempo e no espaço, no recorte contextual, classificá-los e criticá-los a respeito da credibilidade e autenticidade, é o apoio da pretensão à cientificidade do historiador (CARDOSO; PEREZ BRIGNOLI, 2002, p. 39-44).

A ciência histórica do século XX mudou o foco, mas não pôde abrir mão da "inspeção rigorosa" das fontes como instância de verificação da autenticidade, integridade e credibilidade do saber historiográfico. Por inspeção rigorosa se entendem os procedimentos "inquisitoriais" que garantem afastar suficientemente o saber histórico do "puramente" ficcional e imaginativo, para fazê-lo figurar, triunfante, como uma ciência social (BENATTI, 2000, p. 81-82).

No afã de ser ciência, o trabalho historiador seguiu, seja nos trilhos do marxismo economicista, do modelo econômico da segunda geração dos annalistes ou dos modelos estatísticos da cliometria norte-americana, um caminho que levou ao "fetichismo arquivista", culminando na hegemonia de uma história cultural ou da cultura em que o status da prova empírica é tal que as pesquisas são avaliadas mais pelos documentos

\footnotetext{
${ }^{12}$ Foucault apresenta a renúncia aos temas de análise histórica que têm por função "garantir a infinita continuidade do discurso e sua secreta presença no jogo de uma ausência sempre reconduzida" para tratar de reconstituir um outro discurso, "re-estabelecer o texto miúdo e invisível que percorre o interstício das linhas escritas e, às vezes, as desarruma (...). Sua questão, infalivelmente, é: o que dizia, pois, no que estava dito?" In: FOUCAULT, Michel. FOUCAULT, Michel. Arqueologia do saber. Lisboa: Vozes, 1972, p.36-39. Cf. RAGO, Margareth. O efeito-Foucault na historiografia brasileira. Tempo social: Revista de sociologia da USP, São Paulo. v.7, n.1-2, p.73 et seq., out.1995.
} 
(manuscritos ou não) "inéditos" que foi possível reunir do que pela problematização alcançada pelo trabalho (LACAPRA, 1985, p. 80 et seq.).

E, durante algum tempo, os historiadores puderam estar seguros de haver escapado do "meramente literário". Até que "a literatura volta à história, montando seu circo de metáfora e alegoria, interpretação e aporia, exigindo que os historiadores aceitem sua presença zombeteira bem no coração daquilo que, insistiam eles, consistia sua disciplina própria, autônoma e verdadeiramente científica" (HARLAN, 1989).

Pode-se assinalar como emergência deste retorno do literário na cena do saber histórico, o ensaio de Lawrence Stone $O$ renascimento da narrativa: reflexões sobre a velha nova história. ${ }^{13}$ Este texto tinha o intuito de apontar a tendência da pesquisa histórica de ponta ao retorno da forma narrativa de escrita, fazendo na sequência um levantamento das causas dessa tendência. O alvoroço do debate que se seguiu tem menos a ver com o conteúdo da tese de Stone, do que com aquilo que a reabilitação da narrativa com intuito de melhor buscar uma verdade histórica recalca: o caráter retórico e poiético do saber histórico, isto é, o saber como prática cultural produtora (inventora) de sentido (BENATTI, 2002, p. 83-86).

O cenário (assustador?) pode ser vislumbrado nas palavras de Stone:

A tendência para a narrativa levanta problemas irresolvidos sobre a maneira que formaremos nossos graduandos no futuro - supondo que haja algum para formar. Nas artes da retórica? Na crítica dos textos? Em semiótica? Em psicologia? Ou nas técnicas de análise das estruturas sociais e econômicas que viemos praticando durante uma geração? (STONE, 1991, p. 36)

O desdobramento atual é um conflito em que os historiadores tendem a repetir, como forma de convencer a si mesmos, que embora os acontecimentos passados só possam ser conhecidos por intermédio de seu estabelecimento em uma linguagem, eles "ocorreram" num passado "real e empírico" (HUTCHEON, 1996, p. 131-137).

\footnotetext{
13 STONE, Lawrence. O renascimento da narrativa: reflexões sobre a velha nova história. Revista de História, IFCH, UNICAMP, n.2-3, p.13-37, 1991. Este texto analisa o fato de que, a partir da constatação da crise dos modelos de ciência a que a história tentara se converter, havia um retorno, não à forma tradicional de narrativa, mas de um modo de escrever a história que afeta e é afetado pelo conteúdo e pelo método, dirigida por um princípio gerador e que tem um tema e um argumento.
} 
No máximo da "boa vontade" com o lado ficcional do trabalho historiador, entende-se que há necessidade de "preencher lacunas" deixadas pelos documentos, de maneira a organizar uma intriga racional e inteligível. ${ }^{14}$ De forma que:

\begin{abstract}
A história, se a quisermos definir como ficção, há que ter em conta que é uma ficção controlada. A tarefa do historiador é controlada pelo arquivo, pelo documento, pelo caco que chega até o presente. De uma certa forma, eles se "impõem" ao historiador, que não cria vestígios do passado (no sentido de uma invenção absoluta ), mas os descobre ou lhes atribui um sentido, conferindo-lhe o estatuto de fonte (...). Ficção controlada, porque a história aspira ter, em sua relação de "representância" com o real, um nível de verdade possivel (...). Esta história-ficção é ainda submetida às estratégias argumentativas e aos rigores de método, que cercam, testam, comparam e cruzam os documentos escolhidos no maior número de relações e comparações possíveis. (PESAVENTO, 2000, p. 39 e 40)
\end{abstract}

A noção de vestígio, esses indícios de um passado presente, transformados pela metodologia em fonte, documenta o fundamento metafísico da história. O vestígio pretende ser o atestado "material" de que há um limite inconteste para a interpretação e o jogo dentro do trabalho historiador. Procedendo por esta comodidade ético-metafísica, põe-se a escanteio a face aditiva e a influência "nociva" do jogo interpretativo no saber histórico (DERRIDA, 2004, p. 359-360).

Este limite ganha corpo, no que se refere ao trato documental, de duas maneiras. A primeira, já um tanto desgastada, mas ativa - sobretudo nos campos em que a grafia quer se fazer mais científica - é a distinção entre fontes primárias, mais profundas e verdadeiras, e secundárias, superficiais ainda que úteis, mas que não sustentam por si sós um trabalho historiador. Esta hierarquia contempla a noção de "original" e a busca pela "origem" escondida ou perdida nos arquivos, capaz de provar que o historiador diz uma verdade sobre seu "objeto". ${ }^{15}$

Esta primeira hierarquia não desapareceu. Entretanto, a partir dos primeiros embates entre os contornos mais cristalizados da historiografia e os gestos esboçados

\footnotetext{
${ }^{14}$ Cf. VEYNE, Paul. O inventário das diferenças: história e sociologia. São Paulo: Brasiliense, 1983; REIS, José Carlos. Teoria e história da ciência histórica:tempo e narrativa em Paul Ricoeur. In: FIGUEIREDO, Betânia G; CONDÉ, Mauro Lúcio L. (Orgs.). op.cit., 2005. p.96-98.

15 JENKINS, Keith. op.cit., 2005, p.79-83; LACAPRA, Dominick. op.cit., 1985, p.135 et seq. Para estes dois autores, o debate clássico sobre prova documental na historiografia encontra sua melhor performance na contraposição entre os textos de Carr e Elton. Cf. CARR, Edward Hallett. Que é história? 6a ed. Rio de Janeiro: Paz e Terra, 1989; ELTON, Geofrey Rudolph. The practice of history. London: Fontana, 1969.
} 
desde Saussure - que ganharam força e visibilidade a partir da década de setenta, configurando a "virada linguística" - o trabalho com o documento exigiu novos cuidados. A concepção do sistema linguístico como instável e aberto defendida por Derrida, Barthes, Paul de Man e outros se disseminou entre tantas competências disciplinares numa dispersão difícil de domar. ${ }^{16}$ Ante estudos teóricos que insistiam colocar sob suspeição as noções de referente, originalidade, autoria e sentido, bases da "crítica" do documento, houve uma reformulação destas bases, sobretudo na história intelectual, de modo a conformar o que David Harlan chama de "uma nova ortodoxia" (HARLAN, 2002, p. 19 et seq.).

Esta nova ortodoxia estabelece como noções-chave para lidar com a documentação as ideias de contexto e texto. O contexto é tido como um quadro de referência histórica, amplo universo de circunstâncias culturais, dimensão de natureza privilegiada, diversa do texto, que será compreendido e explicado a partir do pressuposto de que compreensão e explicação se devem à restituição de "sentido original" ao documento. O olhar para as fontes é direcionado para se obter delas a forma de seu funcionamento dentro de um tipo de discurso que lhes é exterior, que as contém; e as maneiras pelas quais estes documentos modificam ou são modificadas por este discurso. O documento é instrumento que comprova a existência de um outro: o contexto. É testemunha e representação do que teria existência plena antes dele e sem ele. Ou seja: o interesse recai sobre o "contexto" e não sobre o texto (LACAPRA, 1983, p. 51 et seq.).

O documento vive, desta maneira, uma situação paradoxal. Ele é fundamental na medida em que é o caminho pelo qual se reconstitui a intenção de homens que pensam e agem dentro de um contexto que lhes determina o sentido e a forma da ação. É também a medida de veracidade dessa reconstituição. Mas ele é secundário, já que é sistematicamente reduzido ao ser usado para reconstruir um ou outro contexto. Cada texto documental é aparado até poder ser incorporado ao contexto. A abordagem dos documentos é instrumental, sua historicidade é pontual e restrita à verdade de um contexto previamente delimitado. O documento sobrevive unicamente como expressão e

\footnotetext{
16 "Da filosofia analítica norte-americana à teoria literária estruturalista e pós-estruturalista, da hermenêutica de Gadamer e Ricoeur à teoria dos tropos literários de Hayden White; da história da historiografia à 'metafiç̧ão historiográfica' no romance pós-moderno, como abranger sem disparates tamanha dispersão?" (BENATTI, Antonio Paulo. In: RAGO, M. \& GIMENES,R. (Orgs.). op.cit., p.65-66).
} 
justificativa da presença passada desse contexto, estimando e organizando o trabalho por um sistema de referências diretas ao presente (HARLAN, 2000, p. 39-42).

Num lance dentro desta cena, o trabalho historiador é convidado pelo pensamento derridiano a se disseminar na escrita de história. Pois as tentativas de minimizar os efeitos "perversos" produzidos pela teoria literária e filosofias da linguagem não têm sido suficientes para eclipsar a fenda aberta na unidade desse saber que, como episteme, quis ser uma fusão da letra e sentido metafísico. Tanto que são numerosos os trabalhos que enfatizam a necessidade de se reconhecer e estudar as inter-relações entre esses saberes. No horizonte do pensamento derridiano, como pensar o documento, esse lugar de inscrição, de consignação e de registro? (DERRIDA, 1995, p. 246-247)

Como máquina textual desencadeada, o documento não pode mais ser um fragmento de margens brancas, virgens, vazias. É uma peça cujo limite é imediatamente transbordado por um outro, que o contamina, o excede e faz quebrar seu sentido. Quando o trabalho historiador opera, não há distinção ou hierarquia autêntica entre um tipo de fonte e outro, nem mesmo entre o texto que está sendo tecido e aquele outro, documento, do qual se serve. A função documental nessa operação é suplementar (DERRIDA, 1991, p. 23-26).

A tarefa de um documento numa história absolutamente envolvida com o sentido metafísico, no texto, é de se colocar no lugar onde falta o presente passado, como prova de que ele realmente existiu. A tarefa das fontes é suprir "materialmente" a ausência que funda o saber histórico, evidenciando que seu "objeto" passou pelo mundo como presença e como tal pode ser representado. É encarado, dessa forma, como um complemento, aquilo que torna completo o sentido de outrem. Mas a lógica do suplemento discute o documento como atestado de veracidade e completude de uma ou outra construção histórica. A inserção do documento em um texto quebra a linearidade temporal e pretensa unicidade do discurso histórico, evidenciando a textualidade do trabalho historiador (DERRIDA, 2004, p. 327-386).

"O Suplemento é uma adição, um significante disponível que se acrescenta para substituir e suprir uma falta do lado do significado e fornecer o excesso que é preciso (SANTIAGO, 1976, p. 88).

O trabalho historiador, ao adicionar repetidamente documentos em seu texto, faz ver que a verdade de seu trabalho está fora do seu texto, está no documento, este outro 
texto. E põe à vista, ao mesmo tempo, que este documento só tem valor de verdade neste trabalho. O sentido está intermitente entre o fora e o dentro da operação histórica, e só se deixa produzir nas adições repetidas entre um e outro. Suplementariedade mútua. Se o documento é apresentado como exterior ao trabalho historiador, como referência e local de validação, ele é ao mesmo tempo inserido e integrado à máquina textual, entregando o sentido do texto ao jogo de remissões intertextuais, no qual a plenitude e originalidade da presença passada, a fonte, se apaga (DERRIDA, 2004, p. 263-266).

O documento deveria ser a impressão da coisa em si, da presença que passou, mas a necessidade de transportá-lo e inseri-lo num outro lugar, num texto, indica que esta presença já era lacunar. A escrita derridiana faz aparecer a impossibilidade da presença plena, presente, passada ou futura. Seu labor é intempestivo, de um tempo desconjuntado, fora-de-si. Disseminada, a escrita da história trabalha o documento, não como prova e fragmento de um passado que existiu, mas como suplemento que intervém e se insinua no lugar da presença passada. O documento-suplemento assume, performaticamente, a forma daquilo a que, simultaneamente, ele resiste, substitui e engloba. Tem assim estatuto de suplente e poder de suplência. O trabalho do historiador se transfigura numa encenação intertextual na qual, se há lugar para o sentido, é no desvio e no limite de uma performance de si próprio (DERRIDA, idem, p. 193-200).

O documento-suplemento interrompe a possibilidade de um sentido próprio a qualquer evento ou encadeamento de eventos. Produz-se um efeito interpretativo no qual aquilo que deveria conceder estabilidade e segurança à identidade entre texto e "algo que aconteceu" acaba por perpetrar um deslizamento entre esses limites. Inserir e convocar um documento deveria proteger o texto histórico do desamparo literário, mas se o faz, ao mesmo tempo deixa abrir neste texto a possibilidade de uma outra interpretação, remetendo diretamente à textualidade que constitui, ainda que a contragosto, o campo historiográfico. Dessa maneira, desponta outra forma de lerescrever, feita no lugar e no tempo em que a decisão de fazê-la parece impossível. Essa leitura conjura na máquina textual, por contra-assinatura, os "sujeitos" inseridos no procedimento da máquina a fazer histórias. O "sujeito" que escreve ("historiador"?) e o que escreveu ("agente?" "objeto"?) se rasuram e se deslocam, se desdobram na finitude e perpetuação de seus documentos, registros do "fato" de que um e outro passaram por ali, ainda estão ali, de passagem, a celebrar em cada marca documental sua existência e sua 
morte. O "sujeito" do documento e diante do documento não pode atuar mais como avalista, conselheiro, juiz, promotor, vingador ... a não ser encarando essas funções como máscaras, como assinaturas, parte da máquina que outrora julgou reger (DERRIDA, 1984, p. 75 et seq.).

Uma história não comprometida com a clausura metafísica deliberadamente se aventura, procede como um pensamento errante sobre itinerário e método. As fontes se redobram como suplemento e transbordam, pois não podem nem ser a origem ou presença, e não podem ficar no lugar delas como uma representação, como também não podem ser simplesmente o avesso, uma ficção ou uma mentira. Elas deslocam no texto esses lugares que tendemos a cristalizar. Isto não quer dizer que não haja diferença entre um evento ficcional e um real, mas que a ficção e a realidade são suplementares e são possibilitadas pela máquina textual. Trata-se de não excluir da história(s) aquilo que não está presente e "real" (os inexistentes irreais), e mais: de considerar o evento histórico tido como "real" um caso particular de "ficção". ${ }^{17}$

O que tentamos mostrar ao seguir o fio de ligação do 'perigoso suplemento' é que no que chamamos de vida real das criaturas de carne e osso (...) nunca houve nada além da escrita e nunca houve nada além de suplementos e significações substitutas, que poderiam surgir apenas em uma corrente de referências diferenciais. O 'real' sobrevém e é adicionado apenas ao tomar o sentido de um vestígio ou a evocação de suplementos. (DERRIDA, 2004, p. 196)

Onde quer que estejamos, já estamos em um texto. O trabalho historiador parte já e desde sempre da escrita e por isso suas fontes só fazem derivar e transformar o que nunca foi um sentido próprio. Os documentos não podem reunir-se numa unidade originária, num "contexto" que fosse fonte de emanação ou de proveniência do sentido deles. O que nele [documento] está se mescla com o que poderia ter havido; e o que nele há, se combina com o desejo do que estivesse; e que por isso passa a haver e a estar. É por isso que o alcance do contexto nunca pode ser dissociado da análise do texto, e em função dela, todo contexto é transformador-transformável, exportador e exportável. Recortar o contexto de uma pesquisa histórica é imediatamente corromper a pretensa pureza dele,

\footnotetext{
${ }^{17}$ CULLER, Jonathan. D.; BURROWES, Patricia. Sobre a Desconstrução: teoria e crítica do pós-estruturalismo. Rio de Janeiro: Rosa dos Tempos, 1997.p.122-127. Cf. WHITE, Hayden. O texto histórico como artefato literário. In: Trópicos do discurso: Ensaios sobre a crítica da cultura. São Paulo: EDUsp, 2001. p.97-117.
} 
pois exige que se engendre um limite contextual que por si só não estaria lá. Esse limite, essa finitude, é a condição para que a transformação contextual permaneça sempre aberta. Isso não supõe que os textos devam ser apartados de seus contextos, mas, pelo contrário, que só existem contextos sem nenhum centro absoluto de ancoragem. ${ }^{18}$

A fonte, ao tornar-se, abre o tempo como atraso da origem sobre si mesma. Estratagema de uma encenação que pretende se encerrar nos limites de uma consciência e encetar uma presença. Desdobrar este atraso, espaçar esta operação é expor a temporalidade à aporia, a falta de um traçado. O documento-suplemento (suplemento do suplemento) toma-se como o irreversível que infinitamente se reescreve: enquanto navegação, essa reescrita está para além de diagnósticos, profecias e doutrinações, modos de cercear a errância. As fontes trabalham em rede intertextual, gerando acúmulos e carências que alimentarão outros lances e "novas" histórias. (DERRIDA, 1995, p. 245)

\section{Referências bibliográficas}

CARDOSO, Ciro Flamarion S; PEREZ BRIGNOLI, Hector. O que é a ciência histórica de hoje. In: Os métodos da história: introdução aos problemas, métodos e técnicas da história demográfica, econômica e social. 6a ed. Rio de Janeiro: Graal, 2002. p.39-44.

CULLER, Jonathan. D.; BURROWES, Patricia. Sobre a Desconstrução: teoria e crítica do pós-estruturalismo. Rio de Janeiro: Rosa dos Tempos, 1997.

DERRIDA, J. Margens da Filosofia. Campinas: Papirus, 1991 (MF)

DERRIDA, J. Otobiographies: l'enseignement de Nietzsche et la politique du nom propre. Paris: Galilée, 1984 .

DERRIDA, J. A escritura e a diferença. $2^{\text {a }}$ ed. São Paulo: Perspectiva, 1995.

DERRIDA, Jacques. Circunfissão. BENNINGTON, G. \& DERRIDA, Jacques Derrida. Rio de Janeiro: Jorge Zahar, 1996.

DERRIDA, Jacques. Gramatologia. $2^{\text {a }}$ ed. São Paulo: Perspectiva, 2004. (G)

\footnotetext{
${ }^{18}$ DERRIDA, Jacques. Limited Inc., p.110-111. Lacapra, ao tratar das complexas relações que podem existir entre texto e contexto, formula seis tipos de contextos históricos possíveis. Sua preocupação é menos esgotar os tipos de contexto do que demonstrar o quanto a naturalização da idéia de contexto pode empobrecer a historiografia, sobretudo a história intelectual. Ele lista os seguintes contextos: relação entre intenção do autor e texto; relação entre vida do autor e texto; relação entre sociedade e texto; relação entre cultura e texto; relação entre texto e corpo da escrita; relação entre modos de discurso e texto. Cf. LACAPRA, Dominick. op.cit., 1983. p.36-71.
} 
DERRIDA, Jacques. História da mentira: prolegômenos.(1996).

DERRIDA, Jacques. Limited Inc. Campinas: Papirus, 1991.

DUQUE-ESTRADA, Paulo César. Derrida e a crítica heidegeriana do humanismo. In: NASCIMENTO, Evando. (Org.). Jacques Derrida: pensar a desconstrução. São Paulo: Liberdade, 2005. p.245-255.

GINZBURG, Carlo. Relações de força: história, retórica, prova. São Paulo: Companhia das Letras, 2002.

HARLAN, David. Intellectual History and the Return of Literature. The American Historical Review, Vol. 94, No. 3, Jun. 1989, pp. 581-609.

HARLAN, David. A história intelectual e o retorno da literatura. RAGO, M. \& GIMENES, R. (Orgs.). Narrar o passado, repensar a história. Campinas, São Paulo: UNICAMP/IFHC, 2000. HUTCHEON, Linda. Historicizando o pós moderno: a problematização da história. In: op.cit., p.131-137.

LE GOFF, Jacques. Documento-monumento. In: História e memória. Campinas, SP: Editora da UNICAMP, 2003. p.525-541.

NORRIS, Christopher. Desconstruction against itself: Derrida and Nietzsche. In: Desconstruction and the interests of theory Norman: University of Oklahoma Press, 1989, pp. 187-198.

PESAVENTO, Sandra Jatahy. Fronteiras da ficção: diálogos da história com a literatura. Revista de História das Idéias, Lisboa, v. 21, p.39 e 40, 2000.

\footnotetext{
' Aline Magalhães Pinto

Pesquisadora Pós-Doc, PDJ/CNPq

alinealinemp@gmail.com
} 